\title{
Reduction of the crude protein content of diets supplemented with essential amino acids for piglets weighing 15 to 30 kilograms
}

\author{
Juliana Beatriz Toledo', Antonio Claudio Furlan², Paulo Cesar Pozza ${ }^{2}$, Jocasta Carraro ${ }^{3}$, Gabriel \\ Moresco $^{3}$, Silvia Letícia Ferreira ${ }^{3}$, Adriana Gomez Gallego ${ }^{1}$
}

\author{
1 Programa de Pós-graduação em Zootecnia, Universidade Estadual de Maringá, Maringá - PR, Brasil. \\ ${ }^{2}$ Departamento de Zootecnia, Universidade Estadual de Maringá, Maringá - PR, Brasil. \\ ${ }^{3}$ Curso de Zootecnia, Universidade Estadual de Maringá, Maringá - PR, Brasil.
}

\begin{abstract}
Two experiments were carried out to evaluate the reduction of crude protein (CP) in diets supplemented with synthetic amino acids for piglets of 15 to $30 \mathrm{~kg}$. In the performance assay (Exp I), 60 piglets with initial weight of $15.34 \pm 0.87 \mathrm{~kg}$ and final weight of $30.08 \pm 1.59 \mathrm{~kg}$ were distributed in a randomized block design with six replicates, five treatments and two animals per experimental unit. The treatments consisted of five diets in which the CP was reduced by 1.5 percentage points, resulting in low-protein diets (19.24, 17.74, 16.24, 14.74 and 13.24\%), meeting the requirements of amino acids with inclusion of L-lysine, DL-methionine, L-threonine, L-tryptophan, L-valine and L-isoleucine. The average daily gain and feed conversion according to the Linear Response Plateau model (LRP) were estimated at 14.23 and $14.79 \%$ of CP, respectively. As the $\mathrm{CP}$ levels were reduced, there was an increase in the essential:non-essential amino acids ratio. The plasma urea concentration decreased linearly, indicating that there was a better use for amino acids with the $\mathrm{CP}$ reduction. In the nitrogen balance (Exp II), 30 crossbred barrow piglets with average weight of $21.69 \pm 4.46 \mathrm{~kg}$ were housed in metabolic cages, distributed in a completely randomized design with five treatments and six replicates, and the experimental unit consisted of a piglet. The biological protein value in the diets remained above the ideal (70\%), in which the level of $13.24 \%$ CP corresponded to the highest value. There was no difference in levels of urea in blood and urine. Reduction of protein levels is efficient in decreasing the pollution effect in the excreta, with lower nitrogen excretion in feces and urine.
\end{abstract}

Key Words: biological value, ideal protein, pig, urea

\section{Introduction}

The intensive pig rearing system originates large amounts of waste; therefore, there is a great concern regarding the improvement of productivity and prevention of contamination of the environment with the waste. The nitrogen concentration in manure is relatively high and the excess is converted into substances like nitrate and ammonia, which are harmful to the environment, to the performance of animals, and to the health of animals and humans.

The nutritional advances on the determination of amino acid requirements for pigs, associated with an increased availability of synthetic amino acids, allows the reduction of dietary crude protein levels through the application of the ideal-protein concept, aiming to supply to pigs with balanced amino acids that meet their requirements without excess or deficiency, providing greater efficiency of protein deposition and lower nitrogen excretion.

Received July 3, 2013 and accepted February 26, 2014.

Corresponding author: juliana.b.toledo@gmail.com

http://dx.doi.org/10.1590/S1516-35982014000600004

Copyright (C) 2014 Sociedade Brasileira de Zootecnia. This is an Open Access article distributed under the terms of the Creative Commons Attribution Non-Commercial License, which permits unrestricted non-commercial use, distribution, and reproduction in any medium, provided the original work is properly cited.
The ideal ratio between nitrogen from essential amino acids (EAA) and total nitrogen (TN) for growth or protein deposition will depend on the dietary nitrogen concentration, in which nitrogen-rich diets have a smaller ratio and vice versa. Extreme values (high or low) for the ratio between EAA and TN (EAA:TN) have an adverse effect on performance (Heger, 2003).

Diets with protein levels above the needs of the animal lead the excess amino acids to catabolism and may cause an overload of the liver and kidneys due to the removal of excess nitrogen. The catabolism of amino acids increases the excess heat and impairs the feed intake and consequently the amount of other essential nutrients for production (Miyada, 1999).

This study was conducted to evaluate the performance, nitrogen balance and concentrations of protein and metabolites in the blood and urine of pigs of 15 to $30 \mathrm{~kg}$ fed low-protein diets supplemented with synthetic amino acids.

\section{Material and Methods}

The first assay was conducted to evaluate the performance of piglets of 15 to $30 \mathrm{~kg}$ of live weight and the 
second assay was for nitrogen balance determination. The diets used were the same for both experiments (Table 1).

Diets were formulated based on corn, soybean meal, soybean oil, dicalcium phosphate, limestone, salt, sodium bicarbonate, vitamin + mineral premix, antioxidant, synthetic amino acids and growth promoter Leucomag ${ }^{\circledR}$.

Sodium bicarbonate was used to keep the same electrolyte balance among the experimental diets.

Treatments consisted of five diets in which the protein content was reduced by 1.5 percentage points, so they were considered low-protein (19.24, 17.74, 16.24, 14.74 and $13.24 \%$ ). The diets were formulated so as to contain equal amounts of energy, and according to recommendations of Rostagno et al. (2005), based on the ideal-protein concept, applying the true digestibility coefficients to estimate the values of digestible amino acids.
The amino acid composition of corn, soybean meal, defatted milk powder and whey used in the diet formulation were obtained by high-performance liquid chromatography (HPLC) of Ajinomoto Brazil, and the true digestibility of amino acids from those ingredients was determined as in Rostagno et al. (2005).

The synthetic amino acids used were L-lysine, DLmethionine, L-threonine, L-tryptophan, L-valine and Lisoleucine, whose levels reached or slightly exceeded the recommendations of Rostagno et al. (2005).

After the diet formulation, the provision of EAA over total amino acids was checked. The following were considered essential amino acids: lysine, methionine, threonine, tryptophan, valine, isoleucine, arginine, leucine, phenylalanine and histidine. The essential:non-essential amino acid ratio (EAA:NEAA) was determined by summing

Table 1 - Composition $(\mathrm{g} / \mathrm{kg}$, as fed basis) and nutritional value of diets containing different levels of crude protein for piglets of 15 to $30 \mathrm{~kg}$

\begin{tabular}{|c|c|c|c|c|c|}
\hline \multirow{2}{*}{ Ingredients } & \multicolumn{5}{|c|}{ Crude protein level, $\%$} \\
\hline & 19. 24 & 17.74 & 16.24 & 14.74 & 13.24 \\
\hline Corn & 604.43 & 649.87 & 696.66 & 744.02 & 791.41 \\
\hline Soybean meal, $45 \%$ & 342.81 & 294.77 & 244.93 & 194.34 & 143.75 \\
\hline Soybean oil & 13.63 & 11.81 & 9.47 & 6.90 & 4.33 \\
\hline Dicalcium phosphate & 15.67 & 15.94 & 16.23 & 16.51 & 16.80 \\
\hline Limestone & 5.50 & 5.71 & 5.93 & 6.15 & 6.34 \\
\hline Mineral-vitamin premix ${ }^{1}$ & 5.00 & 5.00 & 5.00 & 5.00 & 5.00 \\
\hline Salt & 6.60 & 5.00 & 3.34 & 1.67 & 0.03 \\
\hline Sodium bicarbonate & 2.60 & 4.90 & 7.35 & 9.80 & 12.20 \\
\hline L-lysine HCL & 1.76 & 3.16 & 4.63 & 6.11 & 7.60 \\
\hline DL-methionine & 1.07 & 1.47 & 1.88 & 2.30 & 2.72 \\
\hline L-threonine & 0.75 & 1.42 & 2.11 & 2.81 & 3.50 \\
\hline L-valine & - & 0.72 & 1.52 & 2.32 & 3.13 \\
\hline DL-tryptophan & - & - & 0.22 & 0.49 & 0.77 \\
\hline L-isoleucine & - & - & 0.55 & 1.37 & 2.20 \\
\hline Antioxidant - BHT & 0.10 & 0.10 & 0.10 & 0.10 & 0.10 \\
\hline Leucomag $^{\circledR 2}$ & 0.10 & 0.10 & 0.10 & 0.10 & 0.10 \\
\hline \multicolumn{6}{|c|}{ Calculated values } \\
\hline Electrolyte balance (mEq/kg) & 222.730 & 222.290 & 222.550 & 222.400 & 221.690 \\
\hline Metabolizable energy (Mcal/kg) & 3.230 & 3.230 & 3.230 & 3.230 & 3.230 \\
\hline Crude protein $(\mathrm{g} / \mathrm{kg})$ & 192.40 & 177.40 & 162.40 & 147.40 & 132.40 \\
\hline Digestible lysine (g/kg) & 11.45 & 11.45 & 11.45 & 11.45 & 11.45 \\
\hline Digestible methionine $(\mathrm{g} / \mathrm{kg})$ & 3.77 & 3.97 & 4.17 & 4.38 & 4.59 \\
\hline Digestible threonine (g/kg) & 7.21 & 7.21 & 7.21 & 7.21 & 7.21 \\
\hline Digestible tryptophan (g/kg) & 2.23 & 1.99 & 1.95 & 1.95 & 1.95 \\
\hline Digestible valine (g/kg) & 7.94 & 7.90 & 7.90 & 7.90 & 7.90 \\
\hline Digestible isoleucine (g/kg) & 7.31 & 6.56 & 6.30 & 6.30 & 6.30 \\
\hline Digestible arginine (g/kg) & 12.78 & 11.39 & 9.95 & 8.49 & 7.02 \\
\hline Digestible leucine (g/kg) & 15.25 & 14.15 & 13.00 & 11.82 & 10.66 \\
\hline Digestible phenylalanine (g/kg) & 8.89 & 8.01 & 7.13 & 6.24 & 5.35 \\
\hline Digestible histidine (g/kg) & 4.75 & 4.35 & 3.94 & 3.51 & 3.09 \\
\hline Calcium (g/kg) & 7.20 & 7.20 & 7.20 & 7.20 & 7.20 \\
\hline Sodium (g/kg) & 3.50 & 3.50 & 3.50 & 3.50 & 3.50 \\
\hline Chloride (g/kg) & 4.73 & 4.07 & 3.36 & 2.65 & 1.96 \\
\hline Potassium (g/kg) & 7.97 & 7.23 & 6.45 & 5.67 & 4.88 \\
\hline EAA:NEAA & $47: 53$ & $48: 52$ & $49: 51$ & $52: 48$ & $54: 46$ \\
\hline Available phosphorus (g/kg) & 4.00 & 4.00 & 4.00 & 4.00 & 4.00 \\
\hline
\end{tabular}

${ }^{1}$ Vitamin and mineral mix for piglets in the nursery phase; composition per kg of the product: vit. A - 1,800,000 IU; vit. D3 - 360,000 IU; vit. E - 4,000 IU; vit. K3 - 600 mg; vit. B1 - $280 \mathrm{mg}$; vit. B2 - $800 \mathrm{mg}$; vit. B6 - $300 \mathrm{mg}$; vit. B12 - 3,600 mg; niacin - 6,000 mg; pantothenic acid - 3,200 mg; biotin - $20 \mathrm{mg}$; folic acid - $80 \mathrm{mg}$; choline - $31 \mathrm{~g}$; Fe - 20,000 mg; Cu - 50,000 mg; Co - 120 mg; Mn - 11,000 mg; Zn - 18,000 mg; Se - 60 mg; I - 200 mg; antioxidant - 20 g; excipient q.s. - 1,000 g.

${ }^{2}$ Leucomag: leucomycin at $30 \%$

EAA: NEAA - essential: non-essential amino acids ratio. 
the total amounts of EAA, then calculating the total AA in the diet (TAA) as a function of the dietary crude protein level; and finally, the amount of NEAA was determined as the difference between TAA and EAA.

In experiment I (performance), 60 crossbred pigs from a commercial strain (30 males and 30 females), with an initial average weight of $15.34 \pm 0.87 \mathrm{~kg}$ and final weight of $30.08 \pm 1.59 \mathrm{~kg}$, were used. Pigs were housed in a nursery masonry shed with suspended floor, covered with fiber cement tiles, arranged in four rooms, each having ten pens and divided by a center aisle. The stalls measured $1.32 \mathrm{~m}^{2}$, with cement floors and feeders in the front and partially slatted plastic floor with a nipple-type drinker in the back. Diets and water were provided ad libitum throughout the experimental period.

The animals were distributed in a randomized block design with five treatments with six replications in time and two animals per experimental unit (EU). The piglets were weighed at the beginning and at the end of the trial, and the feed intake was calculated, so the daily feed intake (DFI), average daily gain (ADG) and feed conversion (FC) of each experimental unit could be obtained.

At the end of the experimental period, blood samples were collected in heparinized tubes (Cai et al., 1994), via cranial vena cava for analysis of urea, creatinine, and total protein in the plasma.

Blood samples were centrifuged $(3,000 \mathrm{rpm}$ for 15 minutes) to obtain the blood plasma and then transferred to Eppendorf tubes, which were properly labeled and stored in a freezer $\left(-18{ }^{\circ} \mathrm{C}\right)$ for later analyses. The analyses were performed in laboratory with in vitro diagnostic test kits from Gold Analisa Ltda.

Aiming to evaluate the parameters of performance, the results were subjected to variance analysis, adopting the following statistical model:

$$
\mathrm{Y}_{\mathrm{ij}}=\mu+\mathrm{B}_{\mathrm{i}}+\mathrm{b}_{1} \mathrm{CP}_{\mathrm{i}}+\mathrm{b}_{2} \mathrm{CPi}_{\mathrm{i}}^{2}+\mathrm{LF}+\mathrm{e}_{\mathrm{ijk}} \text {, }
$$

in which: $\mathrm{Y}_{\mathrm{ij}}=$ dependent variable; $\mu=$ overall constant; $\mathrm{B}_{\mathrm{i}}=$ block effect, where $\mathrm{i}=1,2,3,4,5$ and $6 ; \mathrm{b}_{1}=$ linear regression coefficient as a function of crude protein level; $\mathrm{CP}_{\mathrm{i}}=$ crude protein level, where $\mathrm{T}_{1}=19.24, \mathrm{~T}_{2}=17.74$, $\mathrm{T}_{3}=16.24, \mathrm{~T}_{4}=14.74$, and $\mathrm{T}_{5}=13.24 \% ; \mathrm{b}_{2}=$ quadratic regression coefficient as a function of crude protein level; $\mathrm{LF}=$ lack of fit of the regression model; and $\mathrm{e}_{\mathrm{ijk}}=$ experimental error associated with the observations.

The degrees of freedom from the crude protein level parameter were divided into polynomials. To estimate the requirements quadratic models and/or the Linear Response Plateau model (Braga, 1983) were used, according to best fit of each variable assessed, adopting the lowest sum of square deviations (Rondón et al., 2000).

The initial weight of the piglets was used as a covariate for the variables daily feed intake, average daily gain and feed conversion.

Experiment II consisted of an assay to evaluate the nitrogen balance. Thirty male, castrated crossbred pigs of a commercial strain, with $21.69 \pm 3.46 \mathrm{~kg}$ of average initial live weight, were used.

The animals were housed in metabolism cages, in a room with partially controlled environment. The average minimum and maximum temperatures recorded in the trial period were $20.15 \pm 1.55^{\circ} \mathrm{C}$ and $23.45 \pm 1.23^{\circ} \mathrm{C}$, respectively. The average relative air humidity of the experimental period in morning and afternoon was $38.32 \pm 13.53 \%$ and $62.35 \pm 13.21 \%$, respectively.

The experimental design was set in a randomized block, replicated in time, totaling five treatments and six replications, and the experimental unit consisted of a piglet. The feces and urine were collected as described in Sakomura and Rostagno (2007).

The piglets received two daily meals, provided at $8.00 \mathrm{~h}$ and $16.00 \mathrm{~h}$, in the proportions of 60 and $40 \%$ of the total, respectively. The total daily amount was determined according to the intake in the adaptation phase, based on metabolic weight $\left(\mathrm{kg}^{0.75}\right)$. To avoid wasting and facilitate handling, the diets were moistened with $20 \%$ water, and after each meal, water was supplied at the feeder at the rate of $3 \mathrm{~mL} / \mathrm{g}$ of feed, calculated for each experimental unit, in order to avoid excess water consumption.

The total fecal collection method was adopted, with supplementation of $2 \%$ iron oxide $\left(\mathrm{Fe}_{2} \mathrm{O}_{3}\right)$ in the diets as a marker of the beginning and end of fecal collection. The total amount of feces produced was collected daily and stored in plastic bags and then maintained in a freezer at $-18^{\circ} \mathrm{C}$. Afterwards, it was homogenized and a $20 \%$ sample was taken, dried in a forced-air oven $\left(55^{\circ} \mathrm{C}\right)$ and ground to analyze the nitrogen content.

Urine was collected daily in plastic buckets containing $20 \mathrm{~mL}$ of $\mathrm{HCl} 1: 1$. A $20 \%$ sample was collected daily and frozen at $-18{ }^{\circ} \mathrm{C}$, then homogenized and sampled for nitrogen, urea and creatinine determination. The Kjeldahl method was used for the nitrogen analyses, and for urea and creatinine levels, in vitro diagnostic kits from Gold Analisa Ltda were used.

Blood samples were collected at the end of the experiment via the cranial vena cava for urea, creatinine, total protein, albumin and globulin determination (second experiment). 
Blood samples were centrifuged $(3,000 \mathrm{rpm}$ for 15 minutes) to obtain the blood plasma. Then the plasma was transferred to labeled Eppendorf tubes and stored in a freezer $\left(-18{ }^{\circ} \mathrm{C}\right)$ for further analysis at the Pig Laboratory of the Experimental Farm of Iguatemi. For these analyses, we used in vitro diagnostic test kits from Gold Analisa Ltda. except for globulin concentration, which was obtained by difference after total protein and albumin determination.

The nitrogen intake (NI), fecal nitrogen (FN) and urine nitrogen (UN) were determined by multiplying the nitrogen content by the amount of feed consumed, and excreted in feces and urine, respectively. From these values, we calculated the nitrogen retention $(\mathrm{RN}=\mathrm{NI}-\mathrm{FN}-\mathrm{UN})$, the percentage of retained nitrogen as a function of nitrogen intake, which corresponds to the net protein utilization (NPU $=\mathrm{NR} / \mathrm{NC} \times 100)$ and the percentage of retained nitrogen $(\mathrm{RN})$ in relation to absorbed nitrogen (AN), corresponding to the biological value of the protein $(\mathrm{BVP}=\mathrm{RN} / \mathrm{AN} \times 100)$, as indicated by Adeola (2001). For these variables the calculations were based on the metabolic weight $\left(\mathrm{kg}^{0.75}\right)$.

The nitrogen balance-related variables as well the blood and urine variables were subjected to analysis of variance using the SAEG software (Sistema para Análises Estatísticas e Genéticas, version 7.1), adopting the following statistical model:

$$
\mathrm{Y}_{\mathrm{ij}}=\mu+\mathrm{B}_{\mathrm{i}}+\mathrm{b}_{1} \mathrm{CP}_{\mathrm{i}}+\mathrm{b}_{2} \mathrm{CPi}_{\mathrm{i}}{ }_{\mathrm{i}}+\mathrm{LF}+\mathrm{e}_{\mathrm{ijk}} \text {, }
$$

in which: $Y_{\mathrm{ij}}=$ dependent variable; $\mu=$ overall constant; $\mathrm{B}_{\mathrm{i}}=$ block effect, where $\mathrm{i}=1$ and $2 ; \mathrm{b}_{1}=$ linear regression coefficient as a function of crude protein level; $\mathrm{CP}_{\mathrm{i}}=$ crude protein level, where $\mathrm{T}_{1}=19.24, \mathrm{~T}_{2}=17.74, \mathrm{~T}_{3}=16.24$, $\mathrm{T}_{4}=14.74$, and $\mathrm{T}_{5}=13.24 \% ; \mathrm{b}_{2}=$ quadratic regression coefficient as a function of crude protein level; $\mathrm{LF}=$ lack of fit of the regression model; and $\mathrm{e}_{\mathrm{ij \textrm {k }}}=$ experimental error associated with the observations.
The degrees of freedom from crude protein level parameter were divided into polynomials. To estimate the requirements, quadratic models and/or Linear Response Plateau model (Braga, 1983) were used, according to best fit of each variable assessed, adopting the lowest sum of the square deviations model (Rondón et al., 2000), using the SAEG software (Sistema para Análises Estatísticas e Genéticas, version 7.1).

\section{Results and Discussion}

No differences were found for final weight and daily feed intake $(\mathrm{P}>0.05)$ with reduced crude protein levels (Table 2). These results are similar to those obtained by Ferreira et al. (2003), who observed no influence reducing the crude protein level from 18 to $14 \%$ in the diet of pigs kept in a thermo-neutral environment; however, these authors used only lysine, methionine and threonine as synthetic amino acids.

Tuitoek et al. (1997) and Figueroa et al. (2000) also found no effect of reducing the dietary protein level on the feed intake of piglets of 20 to $50 \mathrm{~kg}$. Because the amino acid imbalance may negatively influence the feed intake (Henry and Sève, 1993) and, consequently, the weight gain, based on the obtained results, it can be inferred that the supplementation of essential amino acids in different diets did not influence the protein quality.

The average daily gain and feed conversion showed a quadratic effect $(\mathrm{P}<0.05)$ as the dietary crude protein level for piglets ( 15 to $30 \mathrm{~kg}$ ) was increased. The estimate for highest average daily gain and best feed conversion is $16.40 \%$ and $16.78 \%$ of crude protein, respectively. However, the best fit to the data was obtained with the Linear Response Plateau (LRP) model, with estimates for highest daily weight gain and best feed conversion at $14.23 \%$ (Figure 1) and $14.79 \%$

Table 2 - Performance of piglets of 15 to $30 \mathrm{~kg}$ fed low-protein diets supplemented with essential amino acids

\begin{tabular}{|c|c|c|c|c|c|c|c|}
\hline \multirow{2}{*}{ Variable } & \multicolumn{5}{|c|}{ Crude protein level, $\%$} & \multirow{2}{*}{$\mathrm{CV}$} & \multirow{2}{*}{ Effect $^{1}$} \\
\hline & 19.24 & 17.74 & 16.24 & 14.74 & 13.24 & & \\
\hline Final weight, kg & 29.798 & 30.015 & 30.919 & 30.494 & 29.185 & 5.201 & NS \\
\hline Daily feed intake, $g$ & 1.219 & 1.248 & 1.246 & 1.275 & 1.263 & 7.428 & NS \\
\hline Average daily gain, $g$ & 605 & 614 & 656 & 633 & 580 & 10.255 & LRP and $Q$ \\
\hline Feed:Gain & 2.028 & 2.032 & 1.900 & 2.020 & 2.175 & 4.947 & LRP and Q \\
\hline \multirow[t]{2}{*}{ Model } & \multicolumn{5}{|c|}{ Regression equation } & Estimate & $\mathrm{R}^{2}$ \\
\hline & \multicolumn{5}{|c|}{ Average daily gain } & & \\
\hline LRP & \multicolumn{5}{|c|}{$279.6311+23.2625 \mathrm{CP}$} & 14.23 & 0.83 \\
\hline \multirow[t]{2}{*}{ Q } & \multicolumn{5}{|c|}{$713 \mathrm{PP}$} & 16.40 & 0.79 \\
\hline & \multicolumn{5}{|c|}{ Feed:Gain } & & \\
\hline LRP & \multicolumn{5}{|c|}{$3.3338-0.0883 \mathrm{CP}$} & 14.79 & 0.98 \\
\hline Q & \multicolumn{5}{|c|}{$6.79245-0.577415 \mathrm{CP}+0.0172085 \mathrm{CP}^{2}$} & 16.78 & 0.79 \\
\hline
\end{tabular}

CV - coefficient of variation; NS - not significant; LRP - Linear Response Plateau; Q - quadratic effect; CP - crude protein. 
of dietary crude protein, respectively. This model provided a better fit of the data, which showed the smallest sum of squared deviations of the option that considered three points on the line $(19.24,17.74$ and 16.24) and two on the plateau (14.74 and 13.24) and the estimated value of $14.23 \%$ $\mathrm{CP}$ for a gain of $611 \mathrm{~g} /$ day.

Kerr and Easter (1995) and Kerr et al. (2003), reducing the protein content from $16 \%$ to $12 \%$, with and without supplementation of essential and non-essential amino acids for piglets with average weight of $19 \mathrm{~kg}$ and $25.3 \mathrm{~kg}$ respectively, found that, in broad terms, piglets fed lowprotein diets supplemented with amino acids grew in the same way as those which received a diet with high protein. Piglets fed diets without amino acid supplementation, however, grew at a slower rate than the others.

The EAA:NEAA ratio may interfere with the metabolism, meaning that the reduction of the protein content may be limited without a minimum supply of nonessential amino acids. Kerr and Easter (1995) found that a diet with $12 \%$ of crude protein supplemented only with lysine, threonine and tryptophan showed lower performance than that obtained with $16 \% \mathrm{CP}$ diet. In another experiment, those authors studied whether this may have occurred because of a deficiency of essential amino acids not used, or deficiency of non-essential amino acids, and found that the animals responded to inclusion of non-essential amino acids.

Brudevold and Southern (1994) reported that a diet supplemented with valine did not result in improved performance of pigs; however, the supplementation of isoleucine, histidine and tryptophan were required for similar growth in pigs fed the positive-control diet.

According to Heger (2003), there is little information available on the ideal EAA:TAA ratio for pigs and poultry. Mitchell et al. (1968) studied the effect of supplementation of four levels of glutamate on a semi-purified diet with a

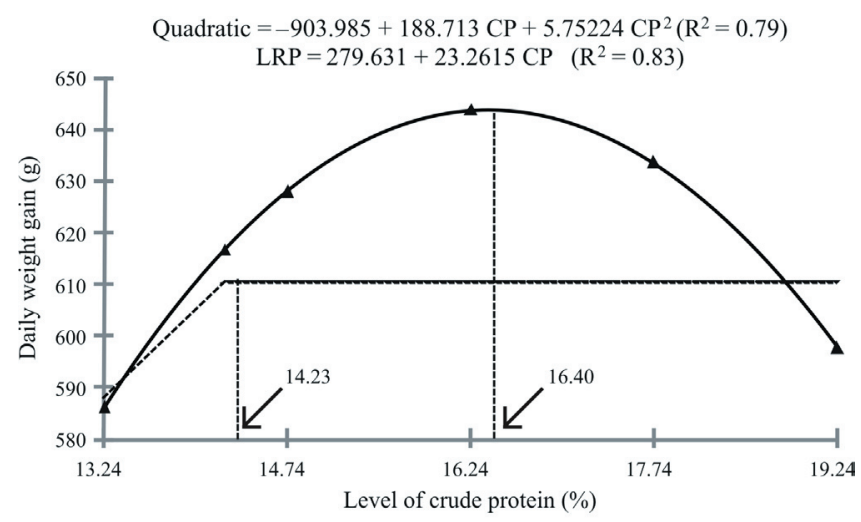

Figure 1- Daily gain of piglets of 15 to $30 \mathrm{~kg}$ fed low-protein diets supplemented with essential synthetic amino acids. constant concentration of essential amino acids for piglets of $10 \mathrm{~kg}$, and observed that the piglets used the dietary nitrogen more efficiently at a 0.40 EAA:TAA ratio. Wang and Fuller (1989) estimated that the ideal ratio between EAA:TAA for growing pigs fed isoprotein diets ranged from 0.34 to 0.58 . Evaluating the nitrogen retention in pigs, Lenis et al. (1999) concluded that, to achieve the maximum nitrogen retention and utilization, this ratio should be 0.5 .

As previously seen, there is a close to optimal variation, in which the response to variation in the EAA:TAA ratio does not change significantly, and the ratio for optimal growth and protein deposition estimated at a constant level of total dietary nitrogen, using the same classification of amino acids, does not significanly differ among species, averaging 0.55 to 0.60 (Heger, 2003). In the present study, as the dietary crude protein levels were reduced, there was an increase in the EAA:NEAA ratio. The crude protein levels that were closest to the ideal were $14.74 \%$ and $13.24 \%$, with a EAA:TAA ratio of 53:48 and 54:46 respectively (Table 1).

There was a linear decrease $(\mathrm{P}<0.05)$ in the plasma urea of piglets of 15 to $30 \mathrm{~kg}$ of body weight as the dietary crude protein level was reduced (Table 3). This effect was verified by other authors (Kerr et al., 1995), who found that reduction of crude protein from $16 \%$ to $12 \%$, with no amino acid supplementation, resulted in moderate increase in the plasma urea level; however, supplementation of lysine, threonine and tryptophan drastically decreases this concentration. In this study, the collected data indicate that the lower excess of amino acids when the dietary crude protein was reduced to $12 \%$ with synthetic-amino-acid supplementation allowed for a reduction in the plasma urea concentrations.

Considering that the serum urea came from the hepatic metabolism of nitrogenous compounds (Stryer, 1996), a lower concentration may be related to the lower catabolism of amino acids for each dietary crude protein reduction.

According to the literature, an appropriate amino acid balance promotes the protein synthesis, with lower catabolism and, consequently, lower synthesis of urea, the major product of this catabolism. Brown and Cline (1974) found high concentrations of urea in the blood serum of pigs fed amino acid-deficient diets. However, the same authors noted that the blood urea concentration decreased as amino acids were supplemented to the diets.

Urea is the main product of the protein catabolism, so higher levels in the blood plasma indicate high dietary protein levels, reflecting in the growth and feed efficiency of pigs. According to Fischer et al. (2000), the study of plasma urea concentration is an indicator of the quality and level of dietary protein, because higher levels 
in the plasma are caused by removal of body nitrogen when the amino acids are metabolized in excess, and this excess is eliminated from the body mainly in the urine. Thus, it can be stated that the protein given to piglets has a high quality and is efficient to decrease the plasma urea levels.

Some studies show that when the crude protein content of the diet is reduced, the animals receive a higher net energy amount compared with the digestible-energy basis. This occurs because the heat increment decreases as the crude protein level is reduced, due to the lower heat production caused by the reduction of the exceeding-amino-acid deamination with smaller synthesis and excretion of urea and lower rate of protein turnover. Pigs spend around $3.6 \mathrm{~kJ}$ of energy to excrete $1 \mathrm{~g}$ of digestible protein. Thus, the energy economy with the partial replacement of crude protein by synthetic amino acids provides higher energy availability for other metabolic processes (Le Bellego et al., 2001).
No difference $(\mathrm{P}>0.05)$ was observed for creatinine and total proteins levels with reduced crude protein. According to Kaneko (1997), values from 1.0 to $2.7 \mathrm{mg} / \mathrm{dL}$ of blood creatinine are considered normal. Elevated levels of blood creatinine indicate that the animal is going through great muscular development, thus the values found in this study may reflect the onset of growth by the animal.

The plasma proteins are sensitive to dietary influence; in most cases, their interpretation becomes difficult. Depletion of the dietary protein causes hypoproteinemy and hypoalbuminemy (Kaneko, 1997), which was not observed in this study.

In experiment II (nitrogen balance), the reduction of the crude protein level resulted in lower nitrogen intake $(\mathrm{P}<0.05)$, in which the consumption of essential amino acids was also changed by supplementation of synthetic amino acids to meet the nutritional requirements (Table 4).

Table 3 - Plasma urea, creatinine and total protein levels of piglets of 15 to $30 \mathrm{~kg}$ fed low-protein diets supplemented with essential amino acids

\begin{tabular}{|c|c|c|c|c|c|c|c|}
\hline \multirow{2}{*}{ Variable } & \multicolumn{5}{|c|}{ Crude protein level, \% } & \multirow{2}{*}{$\mathrm{CV}$} & \multirow{2}{*}{ Effect $^{1}$} \\
\hline & 19.24 & 17.74 & 16.24 & 14.74 & 13.24 & & \\
\hline Urea, mg/dL & 33.376 & 30.544 & 25.247 & 24.711 & 17.883 & 28.996 & $\mathrm{~L}$ \\
\hline Creatinine, $\mathrm{mg} / \mathrm{dL}$ & 1.015 & 1.017 & 1.069 & 1.050 & 1.108 & 14.396 & NS \\
\hline Total protein, $\mathrm{g} / \mathrm{dL}$ & 5.419 & 4.933 & 5.181 & 5.025 & 5.155 & 11.362 & NS \\
\hline \multicolumn{5}{|l|}{ Regression equation } & \multicolumn{3}{|c|}{$\mathrm{R}^{2}$} \\
\hline \multicolumn{5}{|c|}{ Urea $=-13.5114+2.45465 X$} & \multicolumn{3}{|c|}{0.95} \\
\hline
\end{tabular}

CV - coefficient of variation; L - linear effect; NS - not significant.

${ }^{1}$ Regression equation.

Table 4 - Effect of reducing crude protein levels with essential amino acid supplementation on the nitrogen (N) balance of piglets of 15 to $30 \mathrm{~kg}$

\begin{tabular}{|c|c|c|c|c|c|c|c|}
\hline \multirow{2}{*}{ Variable } & \multicolumn{5}{|c|}{ Crude protein level, $\%$} & \multirow{2}{*}{$\mathrm{CV}$} & \multirow{2}{*}{ Effect $^{1}$} \\
\hline & 19.24 & 17.74 & 16.24 & 14.74 & 13.24 & & \\
\hline $\mathrm{N}$ intake (g/day) & 36.65 & 37.33 & 34.19 & 31.69 & 24.83 & 16.32 & - \\
\hline $\mathrm{N}$ intake (g/kg BW ${ }^{0.75} /$ day $)$ & 3.86 & 3.51 & 3.36 & 2.98 & 2.65 & 7.61 & Linear \\
\hline $\mathrm{N}$ excreted in feces (g/day) & 5.22 & 5.78 & 4.81 & 5.07 & 4.54 & 18.89 & - \\
\hline $\mathrm{N}$ excreted in feces $\left(\mathrm{g} / \mathrm{kg} \mathrm{BW}^{0.75} /\right.$ day $)$ & 0.55 & 0.54 & 0.48 & 0.48 & 0.48 & 16.35 & Linear \\
\hline $\mathrm{N}$ excreted in urine (g/day) & 8.99 & 8.95 & 8.27 & 7.50 & 3.88 & 29.99 & - \\
\hline $\mathrm{N}$ excreted in urine $\left(\mathrm{g} / \mathrm{kg} \mathrm{BW}^{0.75} /\right.$ day $)$ & 0.94 & 0.85 & 0.79 & 0.69 & 0.41 & 22.01 & Linear \\
\hline Absorbed N (g/day) & 31.43 & 31.55 & 29.38 & 26.62 & 20.29 & 17.48 & - \\
\hline Absorbed N (g/kg BW ${ }^{0.75} /$ day $)$ & 3.30 & 2.97 & 2.88 & 2.50 & 2.17 & 8.63 & Linear \\
\hline Total excreted N (g/day) & 14.21 & 14.73 & 13.08 & 12.56 & 8.42 & 21.67 & - \\
\hline Total excreted $\mathrm{N}$ ( $\mathrm{g} / \mathrm{kg} \mathrm{BW}^{0.75} /$ day $)$ & 1.50 & 1.39 & 1.27 & 1.17 & 0.90 & 13.51 & Linear \\
\hline Retained N (g/day) & 22.44 & 22.60 & 21.11 & 19.12 & 16.41 & 16.49 & - \\
\hline Retained N (g/kg BW ${ }^{0.75} /$ day) & 2.36 & 2.12 & 2.09 & 1.80 & 1.76 & 10.49 & Linear \\
\hline Retained N/N intake (\%) - NPU & 61.25 & 60.40 & 62.51 & 60.09 & 66.17 & 8.03 & NS \\
\hline Retained/absorbed N (\%) - BVDP & 71.54 & 71.49 & 72.86 & 71.78 & 80.93 & 7.69 & LRP and Q \\
\hline \multicolumn{6}{|l|}{ Regression equation } & $\mathrm{R}^{2}$ & \\
\hline \multicolumn{6}{|c|}{$\mathrm{N}$ excreted in feces $\left(\mathrm{g} / \mathrm{kg} \mathrm{BW}^{0.75} /\right.$ day $)=0.285937+0.0852823 \mathrm{~N}$} & 0.72 & \\
\hline \multicolumn{6}{|c|}{$\mathrm{N}$ excreted in urine $\left(\mathrm{g} / \mathrm{kg} \mathrm{BW}^{0.75} /\right.$ day $)=-0.575404+0.505128 \mathrm{~N}$} & 0.89 & \\
\hline \multicolumn{6}{|c|}{ Absorbed N $\left(\mathrm{g} / \mathrm{kg} \mathrm{BW}^{0.75} /\right.$ day $)=-0.202275+1.14144 \mathrm{~N}$} & 0.97 & \\
\hline \multicolumn{6}{|c|}{ Total excreted N $\left(\mathrm{g} / \mathrm{kg} \mathrm{BW}^{0.75} /\right.$ day $)=-0.289467+0.590411 \mathrm{~N}$} & 0.95 & \\
\hline \multicolumn{6}{|c|}{ Retained $\mathrm{N}\left(\mathrm{g} / \mathrm{kg} \mathrm{BW} \mathrm{W}^{0.75} /\right.$ day $)=0.373129+0.636309 \mathrm{~N}$} & 0.94 & \\
\hline \multicolumn{6}{|c|}{ Retained/absorbed N (\%) - BVDP $($ LRP $)=161.6825-38.119 \mathrm{~N}$} & 1.00 & \\
\hline \multicolumn{6}{|c|}{ Retained/absorbed N (\%) - BVDP $(\mathrm{Q})=225.584-110.697 \mathrm{~N}+19.7721 \mathrm{~N}^{2}$} & 0.82 & \\
\hline
\end{tabular}


Nitrogen intake was lower $(\mathrm{P}<0.05)$ for the treatments with lower protein uptake, because the daily feed intake was based on the metabolic weight, associated with the different crude protein levels of the experimental diets.

The nitrogen excreted in feces and urine as well the absorbed nitrogen and total nitrogen excretion decreased linearly $(\mathrm{P}<0.05)$ due to the reduction of the crude protein levels. The variations that can occur between urinary nitrogen and fecal nitrogen are related to the smaller amounts of nitrogen intake. The nitrogen in the pig manure results from the deamination of amino acids not used for protein synthesis when there is excess or imbalance of amino acids in the diets (Moreira et al., 2004).

Kerr et al. (1995) found a slight increase in the fecal nitrogen excretion of piglets $(22 \mathrm{~kg})$ fed a diet containing $16 \%$ of crude protein compared with those fed $12 \%$ crude protein supplemented with lysine, threonine, and tryptophan; however, this increase was not significant. The lack of difference between diets was probably because the authors used only up to the fourth limiting amino acid (tryptophan).

When the crude protein reduction is dramatic and the inclusion of synthetic amino acids is limited, the results can be unexpected and inconsistent with the original hypothesis, as shown by Figueroa et al. (2002). Yet, the results can be favorable if more essential amino acids are supplemented in the diets for pigs. In the present study, this could be demonstrated by the use of the amino acids tryptophan, valine and isoleucine in addition to lysine, methionine and threonine.

The reduction of nitrogen excreted in urine is perfectly justified because the urine is the primary route of elimination of excess nitrogen in the body of pigs. Dietary protein reduction is an effective practice to reduce environmental pollution. Le Bellego et al. (2001) also found lower urinary nitrogen excretion with the reduction of 18.9 to $12.3 \%$ of crude protein for growing animals. According to the results of Le Bellego and Noblet (2002), every percentage point of decrease in dietary protein is followed by a $12.5 \%$ decrease in urinary nitrogen excretion. A research study conducted by Canh et al. (1998) also confirmed that the excess protein ingested is excreted mainly in the urine.

There was a reduction of approximately $9.5 \%$ in the urinary nitrogen for every percentage point reduced in the protein content of the diets; Kerr and Easter (1995), Canh et al. (1998), and Oliveira et al. (2005) found values close to $11 \%$.

The nitrogen retention decreased linearly $(\mathrm{P}<0.05)$ as the crude protein levels were reduced, meaning that when the percentage of protein in the diet was increased $(19.24 \%)$, there was increase in nitrogen retention.
Several hypotheses have been formulated to explain these results. Studies show that synthetic amino acids are more quickly absorbed than those contained in food proteins, and this difference in the absorption speed would cause a likely imbalance in the site where protein synthesis takes place (Partridge et al., 1985). Kerr and Easter (1995) reported that deficiency of non-essential amino acids can also be a reason for the lower nitrogen retention observed in diets with low amounts of protein. According to Roth et al. (1999), a surplus of essential amino acids is a prerequisite for adequate nitrogen retention.

Another likely explanation for the reduction of nitrogen retention in low-crude-protein diets is that the values of nitrogen excreted in feces and urine can be overestimated in diets with higher protein content, because the metabolic fecal nitrogen and endogenous urinary nitrogen fractions are not considered in these calculations.

The percentage of retained nitrogen in relation to nitrogen intake, which also corresponds to the net protein utilization (NPU), was not affected $(\mathrm{P}>0.05)$ by the reduction of crude protein. These data corroborate the findings of Lordelo et al. (2008), who found that this variable was also not different between treatments with supplementation of valine and isoleucine.

The retained nitrogen in relation to absorbed nitrogen, which corresponds to the biological value of dietary protein (BVDP), responded quadratically $(\mathrm{P}<0.05)$ as the dietary crude protein levels were reduced; however, the best fit was obtained with the Linear Response Plateau (LRP) model, which had an estimate of $2.35 \%$ of nitrogen, equivalent to $14.71 \%$ of crude protein. This model had the lowest sum of squared deviations on the option that considered two points on the line (19.24 and 17.74) and three on plateau (16.24, 14.74 and 13.24) and the highest value for $\mathrm{R}^{2}$, estimating 0.72 as the retained nitrogen:absorbed nitrogen ratio.

By analyzing these data, it is possible to observe that the highest biological value of protein was obtained with the lowest level of crude protein (13.24\%), thus the statistical models did not help to explain these effects in view of the explanations for this parameter.

Figueroa et al. (2002) did not observe high biological value of dietary protein for growing gilts $(41 \mathrm{~kg})$. According to these authors, this is probably because the diet was supplemented only up to tryptophan amino acid. They mentioned that the biological values of diets with synthetic amino acids were higher compared with the control treatment; however, these differences were not significant, like in the present study.

The biological value of the dietary protein refers to the wholesomeness with which the essential amino acids are 
Table 5 - Plasma urea, creatinine, total protein and albumin levels for nitrogen balance in piglets of 15 to $30 \mathrm{~kg}$ fed low-protein diets supplemented with essential amino acids

\begin{tabular}{|c|c|c|c|c|c|c|c|}
\hline \multirow{2}{*}{ Variable } & \multicolumn{5}{|c|}{ Crude protein level, $\%$} & \multirow{2}{*}{$\mathrm{CV}$} & \multirow{2}{*}{ Effect $^{1}$} \\
\hline & 19.24 & 17.74 & 16.24 & 14.74 & 13.24 & & \\
\hline Urea, mg/dL & 32.313 & 30.890 & 25.720 & 27.649 & 31.791 & 27.839 & NS \\
\hline Creatinine, $\mathrm{mg} / \mathrm{dL}$ & 1.056 & 1.023 & 1.149 & 1.064 & 1.126 & 8.396 & NS \\
\hline Total protein, $\mathrm{g} / \mathrm{dL}$ & 4.500 & 4.243 & 4.191 & 4.111 & 4.048 & 16.905 & NS \\
\hline Albumin, g/dL & 2.607 & 2.304 & 2.361 & 2.630 & 2.181 & 13.108 & NS \\
\hline Globulin, g/dL & 1.893 & 1.939 & 1.830 & 1.481 & 1.867 & 43.254 & NS \\
\hline
\end{tabular}

CV - coefficient of variation; NS - not significant.

${ }^{1}$ Regression analysis.

Table 6 - Levels of urea and creatinine in the urine of piglets of 15 to $30 \mathrm{~kg}$ fed low-protein diets supplemented with essential amino acids

\begin{tabular}{|c|c|c|c|c|c|c|c|}
\hline \multirow{2}{*}{ Variable } & \multicolumn{5}{|c|}{ Crude protein level, $\%$} & \multirow{2}{*}{$\mathrm{CV}$} & \multirow{2}{*}{ Effect } \\
\hline & 19.24 & 17.74 & 16.24 & 14.74 & 13.24 & & \\
\hline Urea, mg/dL & 380.98 & 482.16 & 377.03 & 426.83 & 309.06 & 56.80 & NS \\
\hline Creatinine, mg/dL & 15.52 & 25.77 & 29.76 & 35.90 & 24.75 & 48.54 & NS \\
\hline
\end{tabular}

$\mathrm{CV}$ - coefficient of variation; NS - not significant.

${ }^{1}$ Regression analysis.

provided in this diet, i.e., as the level of crude protein in diets is lowered, the amino acid profile is improved and consequently has a better biological value. The foods with high-quality proteins are of animal origin, while vegetables are incomplete in terms of one or more essential amino acids and thus have relatively lower biological value.

No differences were observed for the blood variables with the reduction of the crude protein level and amino acid supplementation to piglets in the starter phase (15 to $30 \mathrm{~kg}$ ) (Table 5).

The nitrogen generated by the catabolism of amino acids is excreted mainly in the form of urea. Urea is the main end product of protein metabolism in humans and other mammals (Nelson and Cox, 2011). The crystalline amino acids, also called synthetic, are absorbed more quickly than the amino acids from the dietary protein, thus reducing the excretion of urea into the environment (Bertechini, 2003). With no difference in this parameter, it can be inferred that the diets presented similar amino acid balance and that the protein provided was of good quality.

The concentration of creatinine in the blood plasma or serum is highly correlated with the amount of lean meat in the pig carcass, and nitrogen intake appears to have little effect on the serum creatinine concentration (Cameron et al., 2003), corroborating the results obtained herein.

The albumin is the major organic protein reserve and amino acid transporter (Kaneko, 1997). It can be used to evaluate the quality of protein nutrition (Babatunde et al., 1990). The absence of difference in the results may be explained by the relatively short time to supply the experimental diets, associated with the fact that albumin takes a relatively long time to cause changes in protein intake.
The urea and creatinine levels in the urine of pigs of 15 to $30 \mathrm{~kg}$ of body weight were not affected $(\mathrm{P}>0.05)$ by reduction in the dietary crude protein levels (Table 6).

Creatinine has its origin in the products of nitrogen metabolism and is continuously removed from the body through the kidneys, since it is not recycled or reabsorbed by the body (González and Scheffer, 2002). For Deguchi (1998), the total amount of daily creatinine eliminated is proportional to the weight of the pigs.

\section{Conclusions}

Reduction in protein content of the diets of piglets is recommended so as to decrease the nitrogen elimination in feces and mainly urine. The crude protein level of the diet fed to piglets of 15 to $30 \mathrm{~kg}$ body weight can be reduced to $14.23 \%$ without compromising their performance. The essential:non-essential amino acids ratio increases as protein levels are reduced. The use of synthetic amino acids improves the use of dietary nitrogen, with lower nitrogen excretion into the environment.

\section{References}

Adeola, O. 2001. Digestion and balance techniques in pigs. p.903-916. In: Swine nutrition. 2nd ed. Lewis, A. J. and Sourthern, L. L., eds. CRC, Boca Raton.

Babatunde, G. M.; Pond, W. G. and Peo Jr., E. R. 1990. Nutritive value of rubber seed (hevea brasiliensis) meal: utilization by growing pigs of semipurified diets in wich rubber seed meal partially replaced soybean meal. Journal of Animal Science 68:392-397.

Bertechini, A. G. 2003. Nutrição de monogástricos. UFLA/FAEPE, Lavras. 
Braga, J. M. 1983. Avaliação da fertilidade do solo: ensaios de campo. UFV/Imprensa Universitária, Viçosa, MG.

Brow, J. A. and Cline, T. R. 1974. Urea excretion in the pig: an indicator of protein quality and amino acid requirements. Journal of Nutrition 4:542-545.

Brudevold, A. B. and Southern, L. L. 1994. Low-protein, crystalline amino acid supplemented, sorghum-soybean meal diets for the 10- to 20- kilogram pig. Journal of Animal Science 72:638-647.

Cai, Y.; Zimmerman, D. R. and Ewan, R. C. 1994. Diurnal variation in concentrations of plasma urea nitrogen and amino acids in pigs given free access to feed or fed twice daily. Journal Nutrition 124:1088-1093.

Cameron, N. D.; McCullough, E.; Troup, K. and Penman, J. C. 2003. Physiological responses to divergent selection for daily food intake or lean growth rate in pigs. Animal Science 76:27-34.

Canh, T. T.; Aarnink, A. J. A.; Schutte, J. B.; Sutton, J. D.; Langhout, D. J. and Verstegen, M. W. A. 1998. Dietary protein affects nitrogen excretion and ammonia emission from slurry of growing-finishing pigs. Livestock Production Science 56:181-191.

Deguchi, E. 1998. Relation between body weight and urinary creatinine in $24 \mathrm{~h}$ in castrated male large white pigs. Animal Science Technology 68:347-350.

Ferreira, R. A.; Oliveira, R. F. M.; Donzele, J. L.; Lopes, D. C.; Orlando, U. A. D.; Resende, W. O. and Vaz, R. G. M. V. 2003. Redução de proteína bruta para suínos machos castrados dos 15 aos $30 \mathrm{~kg}$ mantidos em termoneutralidade. Revista Brasileira de Zootecnia 32:1639-1646.

Figueroa, J. L.; Lewis, A. J. and Miller, P. S. 2000. Nitrogen balance and growth trials with pigs fed low-crude protein, amino acid supplemented diets. Nebraska Swine Report, p.26-28.

Figueroa, J. L.; Lewis, A. J.; Miller, P. S.; Fischer, R. L.; Gómez, R. S. and Diedrichsen, R. M. 2002. Nitrogen metabolism and growth performance of gilts fed standard corn-soybean meal diets or lowcrude protein, amino acid supplemented diets. Journal of Animal Science 80:2911-2919.

Fischer, R. L.; Miller, P. S. and Lewis, A. J. 2000. The use of plasma urea as an indicator of protein status in growing-finishing pigs. Nebraska Swine Report, p.29.

González, F. H. D. and Scheffer, J. F. S. 2002. Perfil sanguíneo: ferramenta de análise clínica, metabólica e nutricional. p.5-17. In: Anais do 29ํㅡㄹ Congresso Nacional de Medicina Veterinária, Gramado. UFPel, Porto Alegre.

Heger, J. 2003. Essential to non-essential amino acid ratios. p.103-124. In: Amino acids in farm animal nutrition. 2nd ed. D’Mello, J. P. F., ed. CAB International, Edinburgh.

Henry, Y. and Sève, B. 1993. Feed intake and dietary amino acid balance in growing pigs with special reference to lysine, tryptophan and threonine. Pig News and Information 14:35-43.

Kaneko, J. J.; Harvey, J. W. and Bruss, M. L. 1997. Clinical biochemistry of domestic animals. 5th ed. Academic Press, San Diego.

Kerr, B. J. and Easter, R. A. 1995. Effect of feeding reduced protein, amino acid supplemented diets nitrogen and energy balance in grower pigs. Journal of Animal Science 73:3000-3008.

Kerr, B. J.; McKeith, F. K. and Easter, R. A. 1995. Effect of performance and carcass characteristics of nursery to finisher pigs feed reduced crude protein, amino acid-supplemented diets. Journal of Animal Science 73:433-440.

Kerr, B. J.; Yen, J. T.; Nienaber, J. A. and Easter, R. A. 2003. Influences of dietary protein level, amino acid supplementation and environmental temperature on performance, body composition, organ weights and total heat production of growing pigs. Journal of Animal Science 81:1998-2007.

Le Bellego, L. and Noblet, J. 2002. Performance and utilization of dietary energy and amino acids in piglets fed low protein diets. Livestock Production Science 76:45-58.

Le Bellego, L.; Van Milgen, J.; Dubois, S. and Noblet, J. 2001. Energy utilization of low-protein diets in growing pigs. Journal of Animal Science 79:1259-1271.

Lenis, N. P.; Van Diepen, H. T. M.; Bikker, P.; Jongbloed, A. W. and Van Der Meulen, J. 1999. Effect of the ratio between essential and nonessential amino acids in the diet on the utilization of nitrogen and amino acids by growing pigs. Journal of Animal Science $77: 1777-1787$

Lordelo, M. M.; Gaspar, A. M.; Le Bellego, L. and Freire, J. P. B. 2008. Isoleucine and valine supplementation of a low-protein corn-wheat-soybean based diet for piglets: growth performance and nitrogen balance. Journal of Animal Science 99:2936-2941.

Mitchell, J. R., Jr.; Becker, D. E.; Harmon, B. G.; Norton, H. W. and Jensen, A. H. 1968. Some amino acid needs of the young pig fed a semisynthetic diet. Journal of Animal Science 27:1322-1326.

Miyada, V. S. 1999. Novas tendências para a nutrição de suínos em clima quente. p.34-60. In: Anais do Simpósio Brasileiro de Ambiência e Qualidade na Produção Industrial de Suínos. Fundação de Estudos Agrários Luiz de Queiroz, Piracicaba.

Moreira, I.; Kutschenko, M.; Furlan, A.C.; Murakami, A. E.; Martins, E. N. and Scapinello, C. 2004. Exigência de lisina para suínos em crescimento e terminação, alimentados com rações de baixo teor de proteína, formuladas de acordo com o conceito de proteína ideal. Acta Scientiarum Animal Sciences 26:537-542.

Nelson, D. L. and Cox, M. M. 2011. Lehninger princípios de bioquímica. 5.ed. Artmed - Sarvier, Porto Alegre.

Oliveira, V.; Fialho, E. T.; Lima, J. A. F.; Bertechini, A. G. and Freitas, R. T. F. 2005. Teor de proteína no metabolismo do nitrogênio e da energia em suínos em crescimento. Ciência e Agrotecnologia 29:866-874

Partridge, I. G.; Low, A. G. and Keal, H. D. 1985. A note on the effect of feeding frequency on nitrogen use in growing boars given diets with varying levels of lysine. Animal Production 40:375-377.

Rondón, E. O. O.; Murakami, A. E.; Furlan, A. C. and Garcia, J. 2000. Exigências nutricionais de sódio e cloro e estimativa do melhor balanço eletrolítico da ração para frangos de corte na fase pré-inicial (1-7 dias de idade). Revista Brasileira de Zootecnia 29:1162-1166.

Rostagno, H. S.; Albino, L. F. T.; Donzele, J. L.; Gomes, P. C.; Oliveira, R. F.; Lopes, D. C.; Ferreira, A. S. and Barreto, S. L. T. 2005. Tabelas brasileiras para aves e suínos: composição de alimentos e exigências nutricionais. 2.ed. Universidade Federal de Viçosa, Viçosa, MG

Roth, F. X.; Gotterbarm, G. G.; Windish, W. and Kirchgessner, M. 1999. Influence of dietary level of dispensable amino acids on nitrogen balance and whole-body protein turnove in growing pigs. Journal of Physiology and Animal Nutrition 81:232-238.

Sakomura, N. K. and Rostagno, H. S. 2007. Métodos de pesquisa em nutrição de monogástricos. Funep, Jaboticabal.

Stryer, L. 1996. Bioquímica. 4.ed. Guanabara Koogan, Rio de Janeiro.

Tuitoek, K.; Young, L. G.; Lange, C. F. M. and Kerr, B. J. 1997. The effect of reducing excess dietary amino acids on growing-finishig pig performance: evaluation of the ideal protein concept. Journal of Animal Science 75:1575-1583.

Wang, T. C. and Fuller, M. F. 1989. The optimum dietary amino acid pattern for growing pigs. Experiments by amino acid deletion. British Journal of Nutrition 62:77-89. 